\title{
BAHAYA KEKURANGAN MINUM AIR PUTIH BAGI KESEHATAN
}

\author{
Zulfa Firda Qurota Ayun \\ IIK STRADA INDONESIA \\ zulfaayun5@gmail.com
}

\begin{abstract}
Abstrak
Saat tubuh kurang minum air putih atau cairan lain, seseorang bisa mengalami dehidrasi. Dehidrasi dapat membuat volume plasma darah yang mengandung protein menurun. Dampaknya, tekanan darah orang yang kurang minum air putih juga bisa ikut turun. Mual dan muntah.

\section{Latar Belakang}

Kurangnya konsumsi cairan merupakan masalah penting di bidang kesehatan karena sel tubuh manusia memerlukan air dalam proses metabolisme. Air sebagai zat gizi tubuh berperan dalam media transportasi dan eliminasi produk sisa metabolisme. Asupan air yang kurang akan menimbulkan masalah kesehatan bagi tubuh.

Meskipun fungsi air sangat penting tetapi sering terabaikan dalam kebiasaan pola makan dan minum keseharian. Tidak semua orang dapat mencukupi untuk kebutuhan cairan tubuhnya. Departemen kesehatan indonesia merekomendasikan cairan terutama air minum, yang harus dikonsumsi untuk orang dewasa adalah 2 liter atau setara 8 gelas setiap hari dimana anjuran ini tidak jauh berbeda dari pernyataan shinya. Selain itu kebutuhan air minum saat remaja akan meningkat dan direkomendasikan sedikitnya 2,3 sampai 3 liter air per hari. Juga menunjukkan bahwa rata - rata asupan total air dari makanan dan minuman pada remaja laki - laki adalah 3,4 liter per hari dan remaja perempuan adalah 2,5 liter per hari.
\end{abstract}

\section{Kasus/masalah}

Mengapa kita harus minum air putih? Karena air tidak terperangkap di dalam tubuh. Setiap hari, air dalam tubuh Anda akan keluar melalui:

- Keringat, sekitar $100 \mathrm{ml}$

- Feses, sekitar $200 \mathrm{ml}$ 
- Urine, minimal $800 \mathrm{ml}$

- Insensible water loss, sekitar $800 \mathrm{ml}$

Total jumlah minimal air yang hilang dari tubuh Anda adalah sekitar $1.900 \mathrm{ml}$. Angka ini tidaklah mutlak dan dapat dipengaruhi oleh beberapa faktor terkait. Apabila Anda berolahraga, keringat yang keluar akan lebih banyak. Jumlah air yang hilang dari feses dan urine juga dipengaruhi oleh banyaknya feses dan urine yang Anda produksi. Insensible water loss adalah air yang hilang dari tubuh dan tidak Anda sadari, yaitu melalui penguapan dari kulit dan jalan napas.

Penting sekali untuk mengganti air yang sudah hilang dari tubuh agar tubuh Anda dapat berfungsi dengan baik. Karena dehidrasi dapat menyebabkan beberapa gangguan seperti kurangnya konsentrasi hingga nyeri kepala. Namun, Anda tidak perlu khawatir karena tubuh memiliki sistem yang dapat memberikan rasa haus saat tubuh kekurangan cairan.

Gantilah air yang hilang tersebut dengan air putih, sebanyak jumlah air yang keluar dari tubuh Anda. Jangan bingung dulu! Para ahli sudah memberikan standar jumlah air minimal yang harus diminum per hari, karena cukup sulit untuk menghitung jumlah air yang keluar dari tubuh tiap-tiap individu. Mereka merekomendasikan untuk minum air sebanyak 2 liter atau kurang lebih 8 gelas per hari.

\section{Tinjauan pustaka}

Air merupakan salah satu asupan penting untuk bahan bakar sel, menjaga fungsi otak, dan menunjang kinerja organ tubuh. Untuk menjaga tingkat hidrasi tubuh, pasokan cairan terbaik bisa diperoleh dari minum air putih. Kebutuhan cairan setiap orang berbeda-beda, tergantung tingkat aktivitas, suhu, dan kondisi kesehatan masingmasing orang. Rata-rata, orang dewasa perlu minum air sebanyak delapan atau sembilan gelas per hari. Saat tubuh banyak mengeluarkan keringat karena aktivitas fisik atau cuaca panas, kebutuhan cairan bisa meningkat. Kurang minum air putih atau cairan lain menyebabkan dehidrasi. Kondisi tersebut bisa berbahaya bagi kesehatan. Berikut beberapa akibat kurang minum air putih yang tak boleh disepelekan:

- Tekanan darah menurun

Saat tubuh kurang minum air putih atau cairan lain, seseorang bisa mengalami dehidrasi. Dehidrasi dapat membuat volume plasma darah yang mengandung protein menurun. Dampaknya, 
tekanan darah orang yang kurang minum air putih juga bisa ikut turun.

- Mual dan muntah

Saat suhu meningkat atau sedang melakukan aktivitas fisik, tubuh manusia secara alami menghilangkan panas di tubuh dengan berkeringat. Apabila pengeluaran cairan tersebut tidak diimbangi dengan asupan cairan pengganti, kenaikan suhu tubuh menyebabkan mual dan muntah.

- Penyakit batu ginjal dan infeksi saluran kencing

Kurang minum air putih dan cairan lainnya juga dapat meningkatkan risiko penyakit batu ginjal dan infeksi saluran kencing. Saat kekurangan cairan, tubuh lebih sulit menghilangkan bakteri biang infeksi saluran kencing. Tak hanya itu, mineral pembentuk batu yang biasanya bisa hilang dengan minum air putih juga bisa mengendap di ginjal.

- Susah berpikir dan sakit kepala

Otak manusia sekitar 80 persen terdiri atas air. Agar kinerja otak bisa optimal, organ vital ini memerlukan asupan air. Akibat kurang minum air putih dan cairan lainnya bisa menyebabkan kinerja otak jadi tidak optimal. Salah satu imbasnya, otak jadi tidak fokus, susah berpikir, mengantuk, susah mengingat sesuatu, sampai sakit kepala.

- Kulit kering

Akibat kurang minum air putih dan cairan lainnya yang pantang disepelekan adalah kulit kering. Kulit perlu tetap terhidrasi agar tetap lembab. Kurang cairan dapat membuat kulit keriput, tidak segar, dan tidak berkilau. Kekurangan cairan di dalam tubuh membuat kolagen pecah, sehingga garis halus dan kerutan di kulit jadi lebih kentara.

Menurut data kesehatan yang dipublikasikan oleh National Kidney Foundation, disebutkan kalau konsumsi air sangat penting untuk membantu darah membawa nutrisi penting dan bersirkulasi di ginjal.

Ketika kamu mengalami dehidrasi maka sistem sirkulasi akan menjadi terhambat. Dehidrasi ringan dapat membuat kamu merasa lelah, sedangkan dehidrasi parah dapat menyebabkan kerusakan ginjal. 
Konsumsi air putih menjadi sangat penting, terutama buat kamu yang sedang bekerja dan aktif berolahraga.

Perlu Anda ketahui, sekitar 3/4 tubuh manusia terdiri dari air. Komponen ini bisa ditemukan pada banyak organ tubuh seperti otot, jantung, tulang, ginjal, paru-paru, dan kulit. Air punya manfaat dan peranan yang sangat penting dalam menjaga sistem kerja tubuh. Air membantu melancarkan pencernaan dan pengeluaran racun dari tubuh, menyeimbangkan kadar mineral, serta menyebarkan oksigen ke seluruh organ.

\section{Pembahasan}

Atasi dehidrasi selain dengan air putih

Selain minum air putih, terdapat beberapa cara untuk mengatasi dehidrasi. Berikut ini adalah makanan dan minuman yang bisa Anda konsumsi untuk mengatasi dehidrasi.

» Susu

Pada sebuah studi dari American Journal of Clinical Nutrition, susu yang penuh lemak dan juga skim ternyata lebih meningkatkan hidrasi dalam tubuh dibandingkan air putih. Selain itu, susu juga menyehatkan karena mengandung protein, karbohidrat, vitamin dan mineral.

» Minuman olahraga

Saat sedang berolahraga dan berkeringat tidak hanya air yang keluar dari tubuh. Laktat, asam amino, lemak dan sodium dalam tubuh juga ikut dikeluarkan melalui keringat. Untuk mencegah dehidrasi, Anda bisa memilih minuman olahraga yang mengandung beberapa ion. Minuman ini dapat menggantikan cairan keringat yang keluar pada tubuh saat berolahraga.

"Air kelapa

Air kelapa juga salah satu jenis cairan yang dapat menghidrasi tubuh. Berbeda dari minuman olahraga, air kelapa rendah akan karbohidrat dan 
mengandung potasium dengan kadar yang cukup tinggi. Rasanya yang segar juga efektif dalam melegakan kehausan.

»Sayuran dan buah-buahan

Tidak hanya dengan minum air atau cairan lain, saat dehidrasi menyerang, Anda juga bisa mengkonsumsi makanan yang mengandung banyak cairan seperti sayuran dan buah-buahan.Berbagai jenis buah yang mengandung banyak air adalah semangka, stroberi, melon, nanas, jeruk, timun, selada, seleri, paprika, dan bayam.

Selain makanan dan minuman di atas, untuk membantu tubuh dalam penyerapan cairan, Anda bisa mengonsumsi makanan seperti granola bar atau roti gandum. Penelitian menunjukkan asupan cairan dengan sedikit makanan lebih baik daripada mengkhawatirkan jenis cairan yang diminum.

\section{Kesimpulan}

Air sangat diperlukan untuk tubuh kita, jika kita sampai mengalami dehidrasi itu akan sangat menggangu kesehatan tubuh kita dan juga bisa berdampak buruk bagi oragan kita. Untuk itu sangat dianjurkan minum air putih setiap hari sesuai anjuran yang telah diberikan di atas.

Selain minum air putih yang cukup kita bisa menjaga pola makan dengan mengkonsumsi sayuran, buah, ikan, danging dan makanan sehat lainya. Selain itu kita juga bisa berolahraga untuk menjaga kesehatan tubuh kita, tidak lupa setelah olahraga konsumsi air putih yang cukup agar tubuh kita tidak mengalami dehidrasi.

\section{Daftra pustaka}

\section{http://scholar.unand.ac.id/20324/2/BAB\%201\%20Pendahuluan.pdf}

https://www.sehataqua.co.id/mengapa-anda-harus-minum-air-putih/

https://health.kompas.com/read/2020/11/18/101000568/12-akibatkurang-minum-air-putih-yang-tak-boleh-disepelekan?page=all (jurnal ke 1)

https://www.halodoc.com/artikel/awas-kurang-minum-air-putih-bisasebabkan-gangguan-ginjal (jurnal ke 2)

https://hellosehat.com/sehat/gejala-umum/12-tanda-anda-kurang- 
$\underline{\text { minum-air-putih/ (jurnal ke 3) }}$

https://www.klikdokter.com/info-sehat/read/3595060/tips-mengatasidehidrasi-selain-minum-air-putih

Damayanti, E. (2021). Sikap Pencegahan Aborsi Ditinjau Dari Pengetahuan Tentang Bahaya

Dan Resiko Kesehatan.

Sodik, M. A., \& Akoit, A. (2016). Looks Personal Hygiene Of Student Senior High Scholl With

The Herpes Disease.

Journal of Global Research in Public Health

Sodik, M. A., \& Saheri, M. (2019). Corelation Study Between Knowledge, Attitude Toward

Tenaager's Sexual Beahaviour Who Was Domiciled In English Village. Journal of Global

Research in Public Health

TAHIN, M. W., \& Sodik, M. A. (2021). Pengaruh Merokok Bagi Remaja Terhadap Perilaku dan Pergaulan Sehari-hari.

Attoriq, S., \& Sodik, M. A. (2018). Pencegahan Dan Pengendalian Infeksi Terkait Pelayanan

Kesehatan Di Lahan Praktik

TAHIN, M. W., \& Sodik, M. A. (2021). Pengaruh Merokok Bagi Remaja Terhadap Perilaku dan Pergaulan Sehari-hari.

Sodik, M. A., Suprapto, S. I., \& Pangesti, D. (2013). Faktor-Faktor Yang Berhubungan Dengan Pelaksanaan Pelayanan Prima Pegawai Di Rsui Orpeha Tulungagung.

STRADA Jurnal IImiah Kesehatan.

Tule, A. R., Siyoto, S., Dwianggimawati, M. S., \& Sodik, M. A. (2018). The Analysis Factors

Affecting Interest In Medication Of Receipt Help Aid Bpjs Participant In Balowerti

Public

Health Center Kediri City.

Journal of Global Research in Public Health

Oktoriani, E. N., Sutrisno, J., Mayasari, E., \& Sodik, M. A. (2018). Analysis of medical record 
complete flexibility to complete claims of health BPJS RS Baptis Kota Batu. Journal of Global

Research in Public Health

Sodik, M. A., Astikasari, N. D., Fazrin, I., Chusnatayaini, A., \& Peristiowati, Y. (2018). Dental

health child with retardation mental and parents behavior.

Indian Journal of Physiotherapy

and Occupational Therapy-An International Journal 